\title{
Effects of methanol leaf extracts of Loranthus micranthus Linn from three host plants on some biochemical indices of diabetic rats
}

\author{
Uwakwe S Onoja ${ }^{1}$, Innocent E Nweze ${ }^{2}$, Nwachukwu Ekere ${ }^{3}$, Philip F Uzor ${ }^{4 \star}$, \\ Onyinyechi B Giginna ${ }^{1}$ \\ ${ }^{1}$ Department of Human Nutrition and Dietetics, ${ }^{2}$ Department of Microbiology, ${ }^{3}$ Department of Pure and Industrial Chemistry, \\ ${ }^{4}$ Department of Pharmaceutical and Medicinal Chemistry, University of Nigeria, Nsukka, 410001, Nigeria
}

*For correspondence: Email: philip.uzor@unn.edu.ng, philuzor4u@yahoo.com; Tel: +234-8037008294

\begin{abstract}
Purpose: To evaluate the effects of Loranthus micranthus leaf extracts from three host plants on the blood glucose, lipid profile and other biochemical indices of diabetic rats.

Methods: The extracts of L. micranthus from Persea americana, Irvingia gabonensis and Cola acuminata were administered (orally at $200 \mathrm{mg} / \mathrm{kg}$ for 14 days) to alloxan-induced diabetic rats with glibenclamide serving as the standard drug. The fasting blood glucose (FBG), lipid profile, hematological indices and liver enzyme functions of the rats were determined. Phytochemical analysis of the extracts was carried out by standard methods.

Results: The extracts reduced $(p<0.05)$ the FBG, low density lipoprotein $(L D L)$, triglycerides and increased $(p<0.05)$ high density lipoprotein $(H D L)$ and hematological parameters of the rats. However, there was no increase $(p>0.05)$ in liver enzymes. Phytochemical screening showed abundance of flavonoids, alkaloids, tannins and terpenoids.

Conclusion: The study revealed that $L$. micranthus extracts from the three host plants possess antidiabetic, hypolipidemic and anti-anemic activities.
\end{abstract}

Keywords: Anemia, Dyslipidemia, Enzymes, Hyperglycemia, Loranthus micranthus, Mistletoe

\begin{abstract}
This is an Open Access article that uses a funding model which does not charge readers or their institutions for access and distributed under the terms of the Creative Commons Attribution License (http://creativecommons.org/licenses/by/4.0) and the Budapest Open Access Initiative (http://www.budapestopenaccessinitiative.org/read), which permit unrestricted use, distribution, and reproduction in any medium, provided the original work is properly credited.
\end{abstract}

Tropical Journal of Pharmaceutical Research is indexed by Science Citation Index (SciSearch), Scopus, International Pharmaceutical Abstract, Chemical Abstracts, Embase, Index Copernicus, EBSCO, African Index Medicus, JournalSeek, Journal Citation Reports/Science Edition, Directory of Open Access Journals (DOAJ), African Journal Online, Bioline International, Open-J-Gate and Pharmacy Abstracts

\section{INTRODUCTION}

Diabetes mellitus is a disease of metabolic origin which is characterized by elevated blood glucose [1]. The global prevalence of diabetes was $2.8 \%$ in 2000 and this may rise to $4.4 \%$ in 2030 [2]. Dyslipidemia, a major cause of heart diseases, has a prevalence of $95 \%$ in diabetes $[3,4]$.
Moreover, diabetic patients are predisposed to anemia due to diabetic complications [5].

The research into newer remedies or alternatives for diabetes will continue because orthodox drugs have serious side effects such as hepatorenal disturbances, hypoglycemia and anemia. Medicinal plants and plant products are 
prized due to their low cost and relative safety. They have been shown to exhibit antidiabetic activity [6, 7]. They also possess both antidyslipidemic and anti-anemic properties [6].

Loranthus micranthus is a parasitic plant and a member of the Loranthaceae family (the mistletoe family). The plant is used traditionally for the treatment of artherosclerosis, diabetes, AIDS, anemia and several other ailments [8]. It has been reported to exhibit hypoglycemic, hypolipidemic and anti-anemic properties $[9,10]$. However, no study has investigated the antidiabetic, anti-hyperlipidemic, anti-anemic, and anti-hepatic dysfunction effects of $L$. micranthus from the host plants- Persea americana, Irvingia gabonensis and Cola acuminata.

This study was aimed at studying the potentials of $L$. micranthus parasitic on the three host plants in the treatment and management of hyperglycemia, and the associated dyslipidemia, anemia and liver enzymes malfunction in diabetic animal models to provide scientific support or otherwise for their claimed efficacy.

\section{EXPERIMENTAL}

\section{Plant materials}

Loranthus micranthus from three host plants, namely, Persea americana (avocado pear tree), Irvingia gabonensis (bush mango tree) and Cola acuminata (kola nut tree) -were freshly harvested from Isienu community in Nsukka, south-eastern Nigeria. The identification of the plants was done at the International Center for Ethnomedicine and Drug Development (InterCEDD), Nsukka, Nigeria by a taxonomist, Mr. Alfred Ozioko. The voucher specimens (nos. InterCEDD/100, InterCEDD/101 and InterCEDD/102, respectively) were deposited in the herbarium of the Department of Plant Science and Biotechnology, University of Nigeria, Nsukka, Nigeria.

\section{Extraction of plant materials}

Fresh leaves of $L$. micranthus from the three host plants (Persea americana, Irvingia gabonensis, and Cola acuminata) were air-dried and then pulverized in a grinder. The powdered samples were labeled $A, B$ and $K$ respectively. A certain quantity $(500 \mathrm{~g})$ each of the powdered samples was macerated in $3000 \mathrm{~mL}$ of methanol for $48 \mathrm{~h}$. Filtration was done with Whatman no. 4 filter paper and the filtrate was concentrated at $40{ }^{\circ} \mathrm{C}$ in a rotary vacuum evaporator (Buchi Rotavapor, china). The yield was $3.1 \%$.

\section{Phytochemical analysis}

The extracts were subjected to preliminary phytochemical screening following standard procedures [11].

\section{Experimental animals}

Twenty five (25) adult male Wistar albino rats (weight: 160-210 g) were used for the study. The animals were given feed (Finishers pellets; Vital Feeds Nigeria Ltd., Enugu) and water ad libitum. The experimental protocol was approved (NHREC/05/01/2008B) by the Ethics Committee of the University of Nigeria. Animal care and handling were in compliance with the international guidelines [12].

\section{Acute toxicity test}

Oral acute toxicity test was done using 48 mice distributed in 12 groups of 4 mice each $(n=4)$. Group I animals (for each extract) was given 2 $\mathrm{ml} / \mathrm{kg}$ body weight of normal saline (control). Groups II, III and IV (for each extract) were administered the extracts from the three plants at the oral doses of 1000,2000 and $4000 \mathrm{mg} / \mathrm{kg}$, respectively. Water and feed were given ad libitum.

\section{Diabetes induction}

Induction of diabetes was done by the administration (single dose, i.p., $150 \mathrm{mg} / \mathrm{kg}$ ) of freshly prepared alloxan monohydrate solution. Confirmation of hyperglycemia was done at $72 \mathrm{~h}$ after injection. Animals having FBG of over 200 $\mathrm{mg} / \mathrm{dL}$ were considered diabetic and used for the study. The blood glucose concentration of the rats was determined using a glucometer and the strips (Accu-Check and SOFTCLIX, Roche). The tip of the tail of the rat was cut and blood sample smeared on the glucometer strip. Readings (in $\mathrm{mg} / \mathrm{dl}$ ) were taken with a glucometer.

\section{Experimental design}

Twenty five (25) diabetic rats were distributed randomly in 5 groups having 5 rats each $(n=5)$. The treatment protocols were as follows: Group I was administered with $200 \mathrm{mg} / \mathrm{kg}$ of A-extract, Group II received $200 \mathrm{mg} / \mathrm{kg}$ of B- extract and Group III received $200 \mathrm{mg} / \mathrm{kg}$ of K-extract. Group IV received $5 \mathrm{mg} / \mathrm{kg}$ of glibenclamide (RBI, USA) while Group V (control) received only $0.2 \mathrm{ml} / \mathrm{kg}$ of normal saline. The various treatments were given orally in single daily administration for 14 days. The FBG of the animals was measured with a glucometer 
(as described above) on the $14^{\text {th }}$ day of treatment.

\section{Determination of biochemical parameters}

The rats were sacrificed on the $14^{\text {th }}$ day of treatment with the aid of chloroform. Blood samples were collected and put into plain and also heparinized sample tubes for serum and hematological analysis respectively [5,13]. The procedures for the analysis have been previously described [13]. The parameters determined in the present study were triglycerides, LDL, HDL, total cholesterol, hematological indices and liver function tests. The analysis was done using the assay kits (Randox Labs Ltd., Ireland) and following the manufacturer's directions.

\section{Statistical analysis}

Analysis of variance (ANOVA) followed by Duncan's post hoc test was done using SPSS software, version 21. Means were considered significantly different at $p<0.05$. The results are presented as mean \pm SEM.

\section{RESULTS}

\section{Acute toxicity}

Results of toxicity and lethality $\left(\mathrm{LD}_{50}\right)$ showed no recorded death even at $4000 \mathrm{mg} / \mathrm{kg}$ of the extracts. This is indicative that the extracts have wide margin of safety.

\section{Phytochemical profile}

The results of phytochemical analysis are depicted in Table 1 . The results show the presence of glycosides, flavonoids, tannins, saponins, volatile oils, polyphenols, steroids, terpenoids, resins, alkaloids and cardiac glycosides.

Table 1: Phytochemical screening of L. micranthus leaf extracts from three host plants

\begin{tabular}{lccc} 
Phytochemical & $\begin{array}{c}\text { A- } \\
\text { Extract }\end{array}$ & $\begin{array}{c}\text { B - } \\
\text { Extract }\end{array}$ & $\begin{array}{c}\text { K- } \\
\text { Extract }\end{array}$ \\
\hline Alkaloids & ++ & + & + \\
Steroids & ++ & + & ++ \\
Volatile oils & + & + & + \\
Resins & + & ++ & + \\
Cardiac glycosides & + & + & + \\
Flavonoids & ++ & ++ & ++ \\
Terpenoids & + & + & + \\
Polyphenols & ++ & + & ++ \\
Saponins & ++ & ++ & ++ \\
Glycosides & + & + & + \\
Tannins & ++ & + & + \\
\hline
\end{tabular}

$A=$ extract from avocado pear tree, $B=$ extract from bush mango tree, $K=$ extract from kola nut tree. $+=$ present moderately, $++=$ present abundantly

\section{Effect of extracts on rat body weight}

Table 3 shows changes in mean body weight of rats fed $200 \mathrm{mg} / \mathrm{kg}$ of $L$. micranthus leaf extracts from the three host plants.

There was a general increase $(p<0.05)$ in the body weight of the treated animals. The increment ranged from 3.8 to $6.9 \%$ with the extract from Cola acuminata producing the highest effect. The food intake by the treated animals was also higher $(p<0.05)$ than the intake by the untreated group.

\section{Effect of the extracts on the lipid profile}

The extracts and glibenclamide produced significant $(p<0.05)$ increase in the concentra-

Table 2: Effect of $L$. micranthus leaf extracts from three host plants and glibenclamide on the FBG level of diabetic rats

\begin{tabular}{|c|c|c|c|c|}
\hline Experimental Group & $\begin{array}{c}\text { Fasting blood } \\
\text { glucose level at } \\
\text { baseline (mg/dL) }\end{array}$ & $\begin{array}{l}\text { Fasting blood sugar } \\
\text { level after alloxan } \\
\text { induction (mg/dL) }\end{array}$ & $\begin{array}{l}\text { Fasting blood sugar } \\
\text { level after 14-day } \\
\text { treatment (mg/dL). }\end{array}$ & $P$-value \\
\hline A-Extract & $65.3 \pm 8.3^{\mathrm{a}}$ & $441.7 \pm 92.1^{\mathrm{c}}$ & $\begin{array}{c}74.3 \pm 15.4^{\mathrm{a}} \\
(83.2 \%)\end{array}$ & 0.00 \\
\hline B-Extract & $70.3 \pm 16.2^{\mathrm{a}}$ & $253.3 \pm 24.0^{b}$ & $\begin{array}{c}77.7 \pm 30.1^{\mathrm{a}} \\
(69.3 \%)\end{array}$ & 0.00 \\
\hline K-Extract & $86.7 \pm 21.4^{\mathrm{a}}$ & $335.7 \pm 95.2^{\mathrm{b}, \mathrm{c}}$ & $\begin{array}{c}62.3 \pm 29.9^{a} \\
(81.4 \%)\end{array}$ & 0.002 \\
\hline Glibenclamide & $76.3 \pm 6.7^{\mathrm{a}}$ & $374.3 \pm 5.1^{a}$ & $\begin{array}{c}68.0 \pm 12.5^{\mathrm{a}} \\
(81.8 \%)\end{array}$ & 0.051 \\
\hline Untreated (control) & $67.7 \pm 4.5^{\mathrm{a}}$ & $271.0 \pm 44.9^{\mathrm{b}}$ & $232.0 \pm 50.7^{\mathrm{D}}$ & 0.002 \\
\hline Significance level & 0.34 & 0.00 & 0.00 & \\
\hline
\end{tabular}

Data are presented as mean \pm SEM $(n=5)$. $A=$ extract from avocado pear tree, $B=$ extract from bush mango tree,$K$ $=$ extract from kola nut tree. Different supercripts indicate values that are different $(p<0.05)$; figures in parenthesis are the per centage reduction in the FBG after alloxan induction 
tion of HDL (Table 4). Results also showed that the extracts as well as glibenclamide lowered ( $p$ $<0.05)$ the triglycerides, total cholesterol and LDL compared to untreated rats. The effects of the extracts and that of glibenclamide on the various biochemical parameters were not different $(p>0.05)$.

\section{Effect of the extracts on the hematological indices of diabetic rats}

The effects of the extracts of $L$. micranthus and glibenclamide on the red blood cell (RBC) count, packed cell volume (PCV), white blood cell (WBC) count, hemoglobin ( $\mathrm{Hb})$ concentration, neutrophiles \% and lymphocytes \% of diabetic animals are depicted in Table 5. The results show that the extracts and glibenclamide produced significant $(p<0.05)$ increase in the WBC, PCV and RBC of the diabetic rats compared with the control. On the other hand, the extracts and glibenclamide produced no significant $(p>0.05)$ changes in the $\mathrm{Hb}$, neutrophil and lymphocyte levels of the diabetic animals.

\section{Effect of extracts on liver enzyme functions of diabetic rats}

Table 6 shows the effect of the extracts on the alanine amino transferase (ALT) activity of diabetic rats. Results showed that the extracts and glibenclamide generally produced $(p<0.05)$ slight increment $(5-8 \%)$ in the ALT level compared with the control animals (25\%). The extracts produced comparable effect with glibenclamide.

Table 7 shows the effect of the extracts on the alkaline phosphatase (ALP) activity of the diabetic rats. Results showed that the extracts decreased $(p<0.05)$ the ALP of the diabetic rats. There was no difference $(p>0.05)$ in the effects of the extracts and glibenclamide on the ALP.

Table 8 presents the effect of the extracts and glibenclamide on the aspartate amino transferase (AST) activity levels in rats. The AST activity level in all the treatment groups decreased $(p<0.05)$ by $8-11 \%$. On the other hand, the untreated animals had increase in AST activity levels. The extracts produced similar effect $(p>0.05)$ on the AST with glibenclamide.

\section{DISCUSSION}

In terms of safety, the extracts were considered safe with high $\mathrm{LD}_{50}(>4000 \mathrm{mg} / \mathrm{kg}$ ). The present results are similar to that of Edem and Usoh [14] who have established that $L$. micranthus is safe and has no hepatocellular damage or adverse biochemical effects in rats. Vijagalakshmi et al [15] have shown that the leaves of $L$. micranthus Linn may not contain deleterious chemicals capable of any form of liver damage. However, the cytotoxic, genotoxic, and mitodepressive effects of $L$. micranthus have been demonstrated

Table 3: Mean body weight changes of diabetic rats fed $L$. micranthus leaf extracts from three host plants and glibenclamide

\begin{tabular}{lcccc}
\hline $\begin{array}{l}\text { Experimental } \\
\text { group }\end{array}$ & $\begin{array}{c}\text { Weight before } \\
\text { experiment }\end{array}$ & $\begin{array}{c}\text { Weight after } \\
\text { experiment }\end{array}$ & \% Difference & Food intake (g) \\
\hline A- Extract & $180.6 \pm 3.2^{\mathrm{a}}$ & $187.4 \pm 2.5^{\mathrm{a}}$ & $3.8 \uparrow$ & $49.6 \pm 2.2^{\mathrm{a}}$ \\
B- Extract & $178.4 \pm 2.3^{\mathrm{a}}$ & $186.8 \pm 3.4^{\mathrm{a}}$ & $4.7 \uparrow$ & $50.2 \pm 3.6^{\mathrm{a}}$ \\
K- Extract & $180.2 \pm 1.2^{\mathrm{a}}$ & $192.6 \pm 2.4^{\mathrm{a}}$ & $6.9 \uparrow$ & $53.4 \pm 2.4^{\mathrm{a}}$ \\
Glibenclamide & $182.3 \pm 2.3^{\mathrm{a}}$ & $193.4 \pm 2.2^{\mathrm{a}}$ & $6.1 \uparrow$ & $52.3 \pm 3.2^{\mathrm{a}}$ \\
Untreated (control) & $180.4 \pm 3.6^{\mathrm{a}}$ & $176.2 \pm 3.2^{\mathrm{b}}$ & $2.3 \downarrow$ & $40.2 \pm 3.6^{\mathrm{b}}$ \\
\hline
\end{tabular}

Data are presented as mean \pm SEM $(n=5)$. $A=$ extract from avocado pear tree, $B=e x t r a c t$ from bush mango tree, $K=$ extract from kola nut tree. Different supercripts indicate values that are different $(p<0.05) \uparrow=$ increase; $\downarrow=$ decrease

Table 4: Lipid profile of diabetic rats administered L. micranthus leaf extracts and glibenclamide

\begin{tabular}{lcccc}
\hline Treatment & $\begin{array}{c}\text { Total cholesterol } \\
(\mathbf{m g} / \mathbf{d L})\end{array}$ & $\begin{array}{c}\text { Triglycerides } \\
(\mathbf{m g} / \mathbf{d L})\end{array}$ & $\begin{array}{c}\text { HDL } \\
(\mathbf{m g} / \mathbf{d L})\end{array}$ & LDL (mg/dL) \\
\hline A-Extract & $45.7 \pm 3.2^{\mathrm{a}}$ & $80.0 \pm 25.5^{\mathrm{a}, \mathrm{b}}$ & $36.5 \pm 16.7^{\mathrm{a}}$ & $12.0 \pm 3.9^{\mathrm{a}, \mathrm{b}}$ \\
B-Extract & $45.3 \pm 3.1^{\mathrm{a}}$ & $32.3 \pm 6.7^{\mathrm{a}}$ & $34.8 \pm 7.1^{\mathrm{a}}$ & $5.9 \pm 0.7^{\mathrm{a}}$ \\
K-Extract & $59.1 \pm 12.4^{\mathrm{b}}$ & $43.5 \pm 20.3^{\mathrm{a}}$ & $42.2 \pm 4.2^{\mathrm{a}}$ & $9.3 \pm 4.0^{\mathrm{a}, \mathrm{b}}$ \\
Glibenclamide & $42.7 \pm 5.3^{\mathrm{a}}$ & $30.9 \pm 8.6^{\mathrm{a}}$ & $35.9 \pm 9.2^{\mathrm{a}}$ & $6.4 \pm 1.3^{\mathrm{a}, \mathrm{b}}$ \\
Untreated (control) & $76.9 \pm 2.0^{\mathrm{c}}$ & $125.1 \pm 46.1^{\mathrm{b}}$ & $28.0 \pm 2.4^{\mathrm{b}}$ & $12.2 \pm 4.1^{\mathrm{b}}$ \\
Significance level & 0.000 & 0.005 & 0.51 & 0.09 \\
\hline
\end{tabular}

Data are presented as mean \pm SEM $(n=5)$. $A=$ extract from avocado pear tree, $B=e x t r a c t$ from bush mango tree, $K=$ extract from kola nut tree. Different supercripts indicate values that are different $(p<0.05)$ 
Table 5: Effect of the extracts of $L$. micranthus from three host plants on the hematological parameters of diabetic rats

\begin{tabular}{lcccccc}
\hline Group & $\begin{array}{c}\text { WBC } \\
\left(\mu \mathrm{L}^{-1}\right)\end{array}$ & $\begin{array}{c}\text { RBC } \\
\left(\mu \mathrm{L}^{-1}\right)\end{array}$ & $\begin{array}{c}\text { PVC } \\
(\%)\end{array}$ & $\begin{array}{c}\mathbf{H b} \\
(\mathbf{m g} / \mathbf{d L})\end{array}$ & $\begin{array}{c}\text { Neut } \\
(\%)\end{array}$ & $\begin{array}{c}\text { Lymph } \\
(\%)\end{array}$ \\
\hline A-Extract & 7600.0 & 220.0 & 38.6 & 12.4 & 27.4 & 67.6 \\
& $\pm 420^{\mathrm{a}}$ & $\pm 52^{\mathrm{a}}$ & $\pm 3.4^{\mathrm{a}}$ & $\pm 0.6^{\mathrm{a}}$ & $\pm 3.8^{\mathrm{a}}$ & $\pm 8.6^{\mathrm{a}}$ \\
B-Extract & 7720.0 & 182.0 & 41.2 & 13.4 & 32.6 & 68.4 \\
& $\pm 540^{\mathrm{b}}$ & $\pm 31^{\mathrm{b}}$ & $\pm 6.4^{\mathrm{a}}$ & $\pm 1.2^{\mathrm{a}}$ & $\pm 5.2^{\mathrm{a}}$ & $\pm 10.4^{\mathrm{a}}$ \\
K-Extract & 7600.0 & 179.0 & 38.2 & 12.5 & 27.2 & 64.6 \\
& $\pm 780^{\mathrm{a}}$ & $\pm 24^{\mathrm{b}}$ & $\pm 4.4^{\mathrm{a}}$ & $\pm 1.0^{\mathrm{a}}$ & $\pm 6.3^{\mathrm{a}}$ & $\pm 6.6^{\mathrm{a}}$ \\
Glibenclamide & 7760.0 & 190.0 & 34.6 & 12.6 & 24.5 & 63.3 \\
& $\pm 520^{\mathrm{b}}$ & $\pm 36^{\mathrm{b}}$ & $\pm 3.8^{\mathrm{b}}$ & $\pm 0.6^{\mathrm{a}}$ & $\pm 4.8^{\mathrm{b}}$ & $\pm 7.2^{\mathrm{a}}$ \\
Untreated (control) & 6260.0 & 172.0 & 36.4 & 13.3 & 26.3 & 62.2 \\
& $\pm 630^{\mathrm{c}}$ & $\pm 52^{\mathrm{c}}$ & $\pm 4.8^{\mathrm{b}}$ & $\pm 1.6^{\mathrm{a}}$ & $\pm 4.2^{\mathrm{b}}$ & $\pm 4.5^{\mathrm{a}}$ \\
\hline
\end{tabular}

Data are presented as mean \pm SEM $(n=5)$, Different supercripts indicate values that are different $(p<0.05) ; W B C$ =white blood cell, $R B C=$ red blood cell, $P C V=$ packed cell volume, $\mathrm{Hb}=$ hemoglobin, Neut= neutrophiles, lymph = lymphocytes, avocado tree (A-extract), bush mango tree (B-extract), kola nut tree (K-extract)

Table 6: Effect of L. micranthus leaf extracts on the ALT of diabetic rats

\begin{tabular}{|c|c|c|c|}
\hline \multirow[t]{2}{*}{ Experimental group } & \multicolumn{3}{|c|}{ ALT (IU/L) } \\
\hline & Before treatment & After treatment & Difference (\%) \\
\hline$A-$ Extract & $38.6 \pm 2.3^{a}$ & $40.4 \pm 2.2^{a}$ & $5 \uparrow$ \\
\hline B - Extract & $36.2 \pm 2.6^{a}$ & $38.4 \pm 2.4^{\mathrm{a}}$ & $6 \uparrow$ \\
\hline $\mathrm{K}$ - Extract & $37.2 \pm 1.8^{\mathrm{a}}$ & $39.2 \pm 1.6^{\mathrm{a}}$ & $5 \uparrow$ \\
\hline Glibenclamide & $37.6 \pm 2.2^{\mathrm{a}}$ & $40.6 \pm 2.6^{\mathrm{a}}$ & $8 \uparrow$ \\
\hline Untreated (control) & $26.8 \pm 3.2^{\mathrm{b}}$ & $33.6 \pm 2.3^{\mathrm{b}}$ & $25 \uparrow$ \\
\hline
\end{tabular}

Table 7: Effect of L. micranthus leaf extracts on the alkaline phosphatase (ALP) activity

\begin{tabular}{lccc}
\hline Experimental group & ALP (IU/L) & Difference (\%) \\
\cline { 2 - 4 } & Before treatment & After treatment & $11 \downarrow$ \\
\hline A - Extract & $20.6 \pm 2.2^{\mathrm{a}}$ & $18.3 \pm 2.8^{\mathrm{a}}$ & $12 \downarrow$ \\
B - Extract & $21.7 \pm 2.1^{\mathrm{a}}$ & $19.2 \pm 2.6^{\mathrm{a}}$ & $11 \downarrow$ \\
K - Extract & $20.4 \pm 3.2^{\mathrm{a}}$ & $18.2 \pm 2.0^{\mathrm{a}}$ & $13 \downarrow$ \\
Glibenclamide & $20.3 \pm 3.4^{\mathrm{a}}$ & $17.6 \pm 2.4^{\mathrm{a}}$ & $22 \uparrow$ \\
Untreated (control) & $22.4 \pm 2.3^{\mathrm{a}}$ & $32.3 \pm 3.3^{\mathrm{b}}$ & \\
\hline Data are presented as mean \pm SEM $(n=5) . A=$ extract from avocado pear tree, $B=$ extract from bush mango tree,$K$ \\
= extract from kola nut tree. Different supercripts indicate values that are different $(p<0.05) ; \uparrow=$ increase; $\downarrow=$ \\
decrease
\end{tabular}

Table 8: Effect of the extracts of $L$. micranthus on the aspartate amino transferase AST activity of diabetic rats

\begin{tabular}{lccc}
\hline Experimental group & \multicolumn{3}{c}{ AST (IU/L) } \\
\cline { 2 - 4 } & Before treatment & After treatment & Difference (\%) \\
\hline A - Extract & $68.4 \pm 3.2^{\mathrm{a}}$ & $61.2 \pm 2.8^{\mathrm{a}}$ & $11 \downarrow$ \\
B - Extract & $64.4 \pm 2.4^{\mathrm{a}}$ & $59.6 \pm 2.0^{\mathrm{a}}$ & $12 \downarrow$ \\
K - Extract & $71.3 \pm 2.6^{\mathrm{a}}$ & $67.6 \pm 2.2^{\mathrm{a}}$ & $5 \downarrow$ \\
Glibenclamide & $63.2 \pm 2.0^{\mathrm{a}}$ & $58.4 \pm 3.4^{\mathrm{a}}$ & $8 \downarrow$ \\
Untreated (control) & $66.8 \pm 3.6^{\mathrm{a}}$ & $74.6 \pm 2.8^{\mathrm{b}}$ & $6 \uparrow$ \\
\hline
\end{tabular}

Data are presented as mean \pm SEM ( $n=5$ per group). $A=$ extract from avocado pear tree, $B=e x t r a c t$ from bush mango tree, $K=$ extract from kola nut tree. Different supercripts indicate values that are different $(p<0.05)$; $\uparrow=$ increase; $\downarrow$ = decrease

in an in vitro study against Allium cepa root cells especially at high doses [16].

All the extracts of $L$. micranthus from the three host plants showed remarkable biological effects in the models tested but the $L$. micranthus from Persea americana showed the greatest effect followed by that from Cola acuminata. The results of the antidiabetic investigations showed that the leaf extracts possess antidiabetic activity in alloxan-induced diabetic rat models which is comparable to the effect of glibenclamide. Alloxan has been shown to produce hyperglycemia in animal model of diabetes either due to complete or partial destruction of $\beta$ - cells of the islet of langerhans $[17,18]$. The antidiabetic 
activity of the extracts from the present study is in accord with the results of the previous antidiabetic investigations on $L$. micranthus from Persea americana and several other host plants $[9,18]$.

The study also shows that the extracts possess anti-hyperlipidemic activity. Diabetes has been associated with various abnormalities in lipid profile $[5,6,17,19]$. Typically in diabetes, the lipoprotein pattern consists of elevated triglyceride (TAG) and LDL levels and low levels of HDL [20]. These lipid abnormalities are due to insulin deficiency or insulin resistance which in turn adversely alters intermediary metabolism of lipids [6] thereby resulting to artherosclerosis. In the present study, the extracts produced antidyslipidemic activity by significantly reducing the TAG, LDL and total cholesterol levels while increasing the HDL level. Previous investigations into the mechanism of action of $L$. micranthus harvested from C. acuminata in mice (at 250 $\mathrm{mg} / \mathrm{kg}$ ) showed that after 21 days, the fractions of methanol extract, particularly n-butanol fraction, produced reduction in total cholesterol, TAG and LDH without affecting HDL significantly [10]. This result is similar to our present findings. Eze-Steven et al. [21], however, reported a significant decrease in the TGA and total cholesterol levels but no significant changes in the LDL and HDL.

The present study also revealed that the extracts improved the hematological indices of the diabetic rats. This is reflected by the increases in WBC, RBC and PCV.

The increase in WBC count may suggest that the extracts are capable of supporting the synthesis of new WBC to boost body's defense mechanisms [22] while the increase in RBC is indicative that the extracts could support synthesis of new RBC. RBC ensures quick recovery from disease conditions by delivering oxygen to the blood tissues and cells. The increase in PCV could suggest that the animals may be recovering from the anemia due to diabetes mellitus [22]. Thus the improvement in hematological indices is indicative of beneficial hematological effect of the plant extracts in diabetes [23] which may be ascribed to the induction of the hemopoietic pathway. The extracts may have some capacity to potentiate the stimulation of erythropoietin which is released by the kidney [22]. The increased body weight of the animals further lends credence to the beneficial effects of the extracts in diabetic and hyperlipidemic states.
In addition to the aforementioned biochemical effects, the extracts also exhibited hepatoprotective effect by decreasing the concentration of the liver enzymes especially the ALP and AST. This implies absence of damage to relevant organs, particularly the liver and kidney. The liver enzymes are also present in many tissues of the body including the kidney, erythrocytes, cardiac and skeletal muscles. Damage to any of these tissues may cause increase in concentration of these enzymes in the plasma.

The phytoconstituents of the extracts were similar to those obtained from earlier reports. The extract of the plant which was harvested from $P$. americana showed high abundance of several phytoconstituents particularly alkaloids [9]. The chemical constituents were season-dependent, being highest during the peak of the rainy season [24]. In addition, several compounds, including alkaloids, steroids, terpenes and polyphenols have been isolated from the plant [25]. The level of phytochemicals in the leaf extracts ensured protective roles against oxidative stress associated with hyperglycemia. Flavonoids such as quercetin, boswellic, rutin and ellagic acid have been shown to possess antidiabetic activity [7]. The observed variations in the biological effects of the extracts could be due to variations in the phytochemical constituents $[7,8]$ which in turn might be due to differences in the phytoconstituents of the host plants [18].

Plants have been reported to contain high amount of phytochemicals and other nutrients that could have been harnessed by the diabetic and anemic animals in the building and restoring of hematological parameters [22]. It has been postulated that glibenclamide could possibly be acting either by enhancing the secretion and/or release of insulin [6]. From our results, it could therefore be suggested that the $L$. micranthus extracts possess similar mechanism of action to that of glibenclamide. The antidiabetic effect of the extracts suggests that they possess antioxidant properties that led to the inhibition in lipid peroxidation in the animals $[7,8]$. The reduction in both cholesterol and triglycerides concentrations could be beneficial in preventing diabetic complications, improving lipid metabolism and preventing artherosclerotic plaque $[5,7]$.

\section{CONCLUSION}

The methanol leaf extracts of $L$. micranthus from Persea americana, Irvingia gabonensis and Cola acuminata possess significant antidiabetic, antihyperlipidemia and anti-anemic properties. Our present findings may provide a scientific 
justification for the traditional use of the extracts in the management of diabetes and its abnormalities.

\section{DECLARATIONS}

\section{Acknowledgement}

Mr A Ozioko is acknowledged for identifying the plants.

\section{Conflict of interest}

No conflict of interest is associated with this study.

\section{Contribution of Authors}

The work was done by the authors named in this article and they declare that all liabilities pertaining to claims relating to the content of this article will be borne by them.

\section{REFERENCES}

1. American Diabetes Association (ADA). Diagnosis and Classification of Diabetes Mellitus. Diab Care 2009; 32 (Suppl 1): S62-S67.

2. Whiting $D R$, Guariguata $L$, Weil $C$, Shaw J. IDF diabetes atlas: global estimates of the prevalence of diabetes for 2011 and 2030. Diabet Res Clin Pract. 2011; 94: $311-$ 321.

3. Chattanda SP, Mgonda YM. Diabetic dyslipidaemia among diabetic patients attending specialized clinics in Daees salaam, Tanzania. Med J 2008; 23(1): 8-11.

4. Devrajani BR, Shah SZ, Soomro AA, Devrajani T. Type 2 Diabetes mellitus: A risk factor for Helicobacter pylori infection. A hospital based case-control study. Int $J$ Diabetes Dev Ctries 2010; 30(1): 22-26.

5. Sheetz MJ. Molecular understanding of hyperglycaemia adverse effects for diabetic complications. J Am Med Ass 2002; 288: 2579-2588.

6. Omonkhelin JO, Innih SO, Anaka ON, lyame OA. Antidiabetic and hypolipidaemic effect of methanol leaf extract of Napoleona vogelii (Lecythidaceae) Hook \& Planch on alloxan-induced diabetes mellitus in rats. Trop J Pharm Res 2014; 13(11): 1903-1909.

7. Maalik A, Khan FA, Mumtaz A, Mehmood A, Azhar S, Atif M, Karim S, Altaf $Y$, Tariq I. Pharmacological applications of quercitin and its derivatives: $A$ short Review. Trop J Pharm Res 2014; 13(9): 1561-1566.

8. Saija A, Tomaino A, Lo Cascio R, Rapisarda P, Dederen $J C$. In vitro antioxidant activity and in vivo photoprotective effect of a red orange extract. Int $J$ Cosmet Sci 1998; 20(6): 331-342.

9. Osabebe PO, Omeje EO, Nworu SC, Uzor PF, David EK, Uzoma JU. Antidiabetic principles of the Eastern Nigeria mistletoe, Loranthus micranthus Linn. parasitic on
Persea americana. Asia Pac J Trop Med 2010a; 3(8): 619-623.

10. Iwalokun BA, Hodonu SA, Nwoko S, Ojo O, Agomo PU. Evaluation of the possible mechanism of antihypertensive activity of Loranthus micranthus: an African mistletoe. Biochem Res Intl. 2011a; 2011: 1-9.

11. Harborne JBC. Phytochemical methods. London, Chapman and Hall, 1998.

12. EEC. Council Directive 86/609/EEC of 24 November 1986 on the approximation of laws, regulations and administrative provisions of the Member States regarding the protection of animals used for experimental and other scientific purposes. Official J Eur Communities 1986; L358: 1-29.

13. Yakubu MT, Ogunro OB. Effects of aqueous extract of Fadogia agrestis stem in alloxan-induced diabetic rats. Bangladesh J Pharmacol 2014; 9: 356-363.

14. Edem DO, Usoh IF. Biochemical changes in Wistar rats on oral doses of mistletoe (Loranthus micranthus). Amer J Pharmacol Toxicol 2009; 4(3): 94-97.

15. Vijagalakshmi $T$, Muthulakshmi V, Sachdanandam $P$. Toxic studies on biochemical parameters carried out in rats with serankoltai nei, a Siddha drug-milk extract of Semecarpus anavardium. Nutr J Ethnopharmacol 2000; 69: 9-15.

16. Iwalokun BA, Oyenuga AO, Saibu GM, Ayorinde J. Analyses of cytotoxic and genotoxic potentials of Loranthus micranthus using the Allium cepa test. Cur Res J Biol Sci. 2011b; 3(5): 459-467.

17. Dubey GP, Dixit SP, Alok S. Alloxan - induced diabetes in rabbits and effects of herbal formulation D-400. Indian J Pharmacol 1994; 26(3): 225-226.

18. Osadebe PO, Okide GB, Akabogu IC. Study on antidiabetic activities of crude methanolic extracts of Loranthus micranthus (Linn.) sourced from five different host trees. J Ethnopharmacol 2004; 95: 133-138.

19. Zhao H-W, Lv F, Meng W-W, Dang H, Sun Z-L, Chen Y, Dai R-J, Deng Y-L, Wu C-M. Anti-hyperlipidaemic effect of flavones-rich Belamcanda Chinensis (L) DC (Iridaceae) leaf extract in ICR mice fed high fat diet. Trop J Pharm Res 2014; 13(10): 1653-1658.

20. Demacker PN, Veerkamp MJ, Bredie SJ, Marcovina SM, de Graaf J, Stalenhoef AF. Comparison of the measurements of lipids and lipoproteins versus assay for apolipoprotein B for estimation of coronary heart diseases risk: a study in familial combined hyperlipidaemia. Atherosclerosis 2000; 153(2): 483-490.

21. Eze-Steven PE, Njoku OU. Antilipidaemic studies of mistletoe (Loranthus micranthus) leaf extracts on diabetes rats. Int/ J Curr Res. 2010; 8: 48-55.

22. Okonkwo CC, Njoku UO, Mbah AM. Anti-anaemic effect of methanol seed extract of Sphenostylis stenocarpa (African yam bean) in Wistar albino rats. Trop J Pharm Res 2013; 7(45): 2907-2913.

23. Hamed SD, Mohhsen JD, Milad RC, Faham KP, Simbarashe $K$. Effect of alcohol extract of Zataria multiflora (Boiss), Satureja bachtiarica (Bunge) and Zaravschanica membranecea (Boiss) on immuno- 
Onoja et al

haematologic factors in rats. Trop J Pharm Res. 2015; 14(11): 1999-2004.

24. Osadebe PO, Omeje EO, Uzor PF, David EK, Obiorah $D C$. Seasonal variation for the antidiabetic activity of Loranthus micranthus methanol extract. Asian Pac $J$ Trop Med 2010b; 3(3): 196 -199.
25. Moghadamtousi SZ, Hajrezaei M, Habsah Kadir A, Zandi K. Loranthus micranthus Linn.: Biological activities and phytochemistry. Evi Based Compl Alt Med 2013; 2013: 1-9. 